\title{
THE RIGHT TO REASONS IN ADMINISTRATIVE LAW
}

\author{
H.L. KUSHNER*
}

\begin{abstract}
It is generally accepted that there is no common law right to reasons in administrative law. The author reviews the law to determine whether such a right exists and whether it has been changed by the enactment of the Charter of Rights. He questions whether a statutory obligation to give reasons should be enacted. Finally, he looks at the effect of failing to comply with such a requirement. He concludes that although the rules of natural justice and the enactment of s. 7 of the Charter of Rights would support a right to reasons, the courts are reluctant to impose such an obligation on the administrative decision-makers. He feels that the legislatures should require reasons. An administrative decision should be ineffective without reasons if such a requirement were imposed either by the courts or the legislatures.
\end{abstract}

"It may well be argued that there is a third principle of natural justice," namely, that a party is entitled to know the reason for the decision, be it judicial or quasi-judicial". ${ }^{2}$ As early as 1875 it is possible to find case authority to support the proposition that if not reasons, at least the grounds upon which a decision has been made must be stated. ${ }^{3}$ Certainly there is an abundant number of governmental reports and studies, ${ }^{4}$ as well as academic writings ${ }^{5}$ which support the value of reasons. However, the majority of these adopt the view that a requirement for reasons does

* Professor, University of British Columbia.

1. The first two principles are: "No man a judge in his own cause" (Nemo judex in re sua) and "Hear the other side" (Audi alteram partem), H.W.R. Wade, Administrative Law (5th ed., 1982).

2. Report of the Committee on Minister's Powers (The Donoughmore Report), Cmnd. 4060 (1932), p. 80.

3. R. v. Sykes (1875), 1 Q.B.D. 52, at pp. 53-54. See also R. v. Justices of Ashton-Under-Lyne (1873), 37 J.P. 85; Ex Parte Smith (1878), 3 Q.B.D. 374; R. v. Justices of Cumberland Ex Parte Waiting (1881), 8 Q.B.D. 369 R. v. Thomas, [1892] 1 Q.B. 426; but contra Ex Parte Gorman, [1894] A.C. 23; See also text at notes 81-84.

4. In the United Kingdom, there was the Donoughmore Report, supra, note 2; The Franks Report (Report of the Committee on Administrative Tribunals and Enquiries) Cmnd. 218 (1957), paragraph 98; Administration Under Law, A Report by Justice, 1971, par: 51-53; In Canada, the McRuer Commission (The Royal Commission Inquiry into Civil Rights) 1968, p. 218; Report of Civil Rights, Part 3, Procedure Before Statutory Agencies, The Law Reform Commission of British Columbia, Report on Civil Rights, Part 3, Procedures before Statutory Agencies (1974), p. 53; The Report of the Special Committee on Boards and Tribunals to the Legislative Assembly of Alberta, 1965, pp. 35-36; Independent Administrative Agencies, Working Paper \#25, Law Reform Commission of Canada, pp. 137. 138; In Australia, The Bland Report (Committee on Administrative Discretions) Parliamentary Paper No. 316, 1973, par. 172(a)(ii); The Kerr Report (Commonwealth Administrative Review Committee), Parliamentary Paper No. 144, 1971, pp. 78.79; Working Paper on the Judicial Review of Administrative Decisions, Project \#26, Part II, The Law Reform Commission of Western Australia, Chap. 11; The Statute Law Revision Committee Upon Prerogative Writs 1971-72, Victoria.

5. M. Akehurst, "Statement of Reasons for Judicial and Administrative Decisions" (1970), 33 Modern L.R. 154; G.A. Flick, Natural Justice, Principles and Practical Application (1979), Ch. 5; G.A. Flick, "Administrative Adjudication and the Duty to Give Reasons", [1978] Public Law. 16; M. Taggart, "Should Administrative Tribunals be Required to State Findings of Fact" (1980), N.Z.U.L.R. 162; K.J. Keith. "A Code of Procedure for Administrative Tribunals" (1974), Legal Research Foundation, School of Law, Auckland, New Zealand, Pamphlet Number 8; J.W. Bridge, The Duty to Give Reasons for Decisions as an Aspect of Natural Justice, in D. Lasok, A.J.E. Jaffey, D.L. Perrott and C. Sachs (eds.), Fundamental Duties (1980), Ch. VIl. In addition, see also H.W.R. Wade, Administrative Law (5th ed. 1982) and De Smith's Judicial Review of Administrative Law (1980). 
not presently form part of the law of natural justice nor stand as an independent ground for judicial review except possibly where the requirement is imposed by statute. ${ }^{6}$ It is the purpose of this paper firstly to review the concept of a right to reasons in order to determine whether such a right now exists in Canada either by way of the common law (through the concepts of natural justice or procedural fairness) or as a result of the enactment of the Charter of Rights. Secondly, if such a right does not presently exist, should a statutory obligation to give reasons be enacted? Lastly, what is the effect of a failure to comply with any such obligation? However, as a starting point it might be useful to briefly review the value served by requiring administrative decision makers to give reasons in the exercise of their power.

\section{THE VALUE OF REASONS}

A canvass of the reports and articles written as well as judicial decisions reveals that the value of reasons is primarily three-fold.

\section{A. REASONS MAKE THE DECISION MORE ACCEPTABLE TO THE PARTIES INVOLVED.}

It has been said that a fundamental requirement of fair play is that the parties know at the end of the day why a particular decision was made.? Both the decision and the process by which the decision was reached are more likely to be accepted if one is able to judge the soundness of the decision. ${ }^{8}$ By providing reasons the parties are able to determine what the decision-maker considered relevant and what the reasoning process was. Thus in any subsequent re-hearing or re-consideration the parties know what matters to stress. Further, reasons allow the parties to decide whether any further action, by way of an appeal or judicial review, should be undertaken. ${ }^{9}$

\section{B. REASONS PROMOTE BETTER ADMINISTRATIVE DECISION MAKING.}

The giving of reasons ensures that the decision-maker has considered all relevant factors and acts as a check on the exercise of discretion. ${ }^{10} \mathrm{It}$ requires the board to evoke care and prevents arbitrariness." Further, it

6. All except for Bridge, supra, n. 5, accept the view that a requirement for reasons does not form part of the law of natural justice.

7. Franks Report, supra, n. 4, at para. 351; Breen v. Amalgamated Engineering Union, [1971] 2 Q.B. 175, at p. 191 per Lord Denning M.R. (dissent).

8. Bridge supra, n. 5, p. 82; Taggart, supra, n. 5, p. 167; Proulx v. Public Service Staff Relations Board, [1978] 2 F.C. 133 (C.A.) per Jackett C.J. at p. 141.

9. Bridge, supra, n. 5, p. 83; Taggart, supra, n. 5, p. 167; Flick, supra, n. 5, p. 87; Franks Report, supra, n. 4, para. 98; British Columbia Law Reform Commission, supra, n. 4, p. 53; Northwestern Utilities Ltd. v. City of Edmonton, [1979] I S.C.R. 684, p. 706; 89 D.L.R. (3d) 161, p. 175.

10. Flick, supra, n. 5, p. 87-88; Proulx v. Public Service Staff Relations Board, supra, n. 8, p. 141, footnote 6; O'Hanlon v. Municipal District of Foothills Number 3I, [1979] 6 W.W.R. 709 (Alta. C.A.).

11. Taggart, supra, n. 5, p. 167; Flick, supra, n. 5, p. 88; Northwestern Utilities Ltd. v. City of Edmonton, supra, n. 9, p. 706 (S.C.R.), 175 (D.L.R.). 
makes patent the Board's impartiality. ${ }^{12}$ Reasons also assist in the development (over a period of time) of a systematic and consistent process of decision-making by the creation of a form of precedent. Although boards are generally not bound by precedent, a set of reasoned and rational decisions helps to ensure that like cases are treated in a like manner. ${ }^{13}$ If public access to this ordered system of decision-making is available, it may also result in an improvement in the arguments and presentations made to the decision-maker by assisting parties in determining what matters are relevant and important. ${ }^{14}$

\section{REASONS FACILITATE THE COURT'S EXERCISE OF THEIR SUPERVISORY JURISDICTION.}

The Superior Courts exercise a supervisory power, either by way of statute (appeal) or by their inherent powers (judicial review), over inferior decision-makers. If these decision-makers provide reasons for their decision then the courts when exercising their supervisory power know why a particular decision was made. ${ }^{15}$ Proper reasons should show the relationship between the evidence which was led and the decision which was reached. ${ }^{16}$ Reasons enable the Court to determine whether irrelevant considerations have been taken into account or relevant considerations ignored. Further, reasons would broaden the scope of review under the concept of error of law on the face of the record since the record would now include not only the decision but also the reasons. ${ }^{17}$

A further value served by a requirement to give reasons is that it may encourage public confidence in the decision-making process. ${ }^{18} \mathrm{By}$ exposing the decision making process to public scrutiny and criticism, the administrative process becomes subject to external judgment of its value and usefulness. Ultimately the "long term acceptability of the (judicial) system must depend upon the acceptability of the decision which flows from it." 19 By adopting an open approach the decision is more likely to be acceptable to the parties involved, future potential parties and the world at large. ${ }^{20}$

12. Bridge, supra, n. 5, p. 83; Proulx v. Public Service Staff Relations Board, supra, n. 8, p. 141.

13. Taggart, supra, n. 5, p. 167.

14. British Columbia Law Reform Commission, supra, n. 4, p. 53.

15. Taggart, supra, n. 5, p. 166; Proulx v. Public Service Staff Relations Board, supra, n. 8, p. 142 (LeDain $\mathrm{J}$., in dissent).

16. Flick, supra, n. 5, p. 103; Northwestern Utilities Ltd. v. City of Edmonton, supra, n. 9, p. 707 (S.C.R.), p. 176 (D.L.R.). See also text at notes 153-176.

17. Keith, supra, n. 5, p. 34; De Smith, supra, n. 5, pp. 400-408. R. v. Knightsbridge Crown Court, ex parte International Sporting Club (London) Ltd., [1982] Q.B. 304. See also, Ontario, Statutory Powers Procedure Acts S.O. 1971, c. 47, s. 20 (reasons included as part of the record); British Columbia, Judicial Review Procedure Act, R.S.B.C. 1979, c. 209, s. 1, definition of record (includes reasons, if any given).

18. Taggart, supra, n. 5, p. 167; Flick, supra, n. 5, p. 87; Bridge, supra, n. 5, pp. 82-83.

19. Bridge, supra, n. 5, p. 82.

20. For a discussion of the American perspective of the value of "the right to an adequate explanation" see Rabin, "Job Security and Due Process: Monitoring Administrative Discretion Through a Reasons Requirement (1976), 44 U.Chi.L.Rev. 60, at pp. 74-87. 
Criticism of a requirement for reasons is primarily one of bureaucratic negativism. The giving of reasons, it is argued, is too onerous, too expensive, too time-consuming and too difficult. ${ }^{21}$ In response, it can be stated that the bureaucrats have not successfully made out their argument, at least as a general proposition applicable to all decision-makers. Statutes requiring the giving of reasons have been enacted in a variety of jurisdictions. ${ }^{22}$ Some exceptions are provided for, acknowledging, in part, the validity of some of the arguments against the giving of reasons. ${ }^{23}$ However, the general statutory rule appears to be one which favours disclosure. It is submitted that those who argue against a reasons requirement ought to carry the burden of persuasion. If such a requirement will be too time-consuming or expensive, let that be shown, not simply put forward as a vague general assertion. As for being too onerous a duty, once a board has considered the matter and reached a conclusion is it too much to require the board to reduce their view to paper? ${ }^{24}$

A further point, which is invariably made whenever a right to reasons requirement is raised, is the non-obligation of the courts to give reasons for their decisions. If natural justice does not require courts to state their reasons, why should it so obligate administrative decision-makers? One approach would be to argue that courts are so obliged, if not by law $^{25}$ at least by custom. ${ }^{26}$ The courts have recognized an obligation to give reasons where possible. ${ }^{27}$ Alternatively, one may simply argue that the failure of Courts to be obliged to give reasons does not answer the question of whether an administrative decision-maker should. ${ }^{28}$ Boards and Courts are not the same. Boards lack the traditional guarantees of judicial independence such as security of tenure or freedom from political interference. Further, the individual decision-makers may not have had any legal training. Thus additional requirements may be required to be imposed in order to ensure that not only is justice done but that it is seen to be done.

As can be seen from the above discussion, the values served by a reasons requirement tend to overlap. Reasons promote rational decision making and accountability. It requires a decision-maker to explain how a particular decision was reached, to "sift through conflicting factual

21. Flick, supra, n. 5, p. 89; Bridge, supra, n. 5, p. 90; Taggart, supra, n. 5, pp. 175-181.

22. In Canada, the Province of Ontario, Statutory Powers Procedure Act, R.S.O. 1980, c. 484, s. 17 and the Province of Alberta, The Administrative Procedures Act, R.S.A., 1980, c. A2, s. 7; In the United Kingdom, The Tribunal and Inquiries Act 1971, c. 62, s. 12; In Australia, the Administrative Appeals Tribunal Act 1975, s. 28, Administrative Decisions (Judicial Review) Act 1977, s. 13, the State of Victoria, The Administrative Law Act 1978, s. 8.

23. The Tribunal and Inquiries Act 1971, supra, n. 22, s. 12(2), The Administrative Decision's (Judicial Review) Act 1977, supra, n. 22, s. 13(a); The Administrative Law Act 1978, supra, n. 22, s. 8(5). See infra text at notes 121-140.

24. Keith, supra, n. 5, p. 36; Bridge, supra n. 5, p. 90.

25. Bridge, supra, n. 5; see also Eagil Trust Co. Ltd. v. Pigott-Brown [1985] 3 All E.R. 119 (C.A.).

26. M. Taggart, "Should Canadian Judges be Legally Required to Give Reasoned Decisions in Civil Cases?" (1983), 33 U.T. L.J.1.

27. MacDonald v. The Queen (1976), 68 D.L.R. (3d) 649, at p. 654-55, [1977] 2 S.C.R. 665, at p. 672; see also Taggart, supra, n. 26.

28. P.P. Craig, Administrative Law (1983), at 49. 
statements and consider whether there is a reasonable basis for his conclusions." ${ }^{29}$ It permits a Court to exercise their supervisory powers on a more informed basis. Although the introduction of a reason requirement may impose costs upon the administrative system, it remains as the "core safeguard against arbitrariness." 30

\section{THE COMMON LAW}

\section{A. NATURAL JUSTICE}

As indicated at the outset, the accepted view is that natural justice does not compel the giving of reasons. ${ }^{31}$ Both English and Canadian authorities support this proposition. In the case of McInnes v. Onslow Fane ${ }^{32}$ Vide-Chancellor Megarry specifically stated that at common law there was "no general obligation to give reasons for a decision." 33 This view was recently re-affirmed by the Court of Appeal in Payne v. Lord Harris of Greenwich. ${ }^{34}$

In Canada, the no obligation principle is supported by a number of cases. In Pure Spring Co. Ltd. v. Ministry of National Revenue ${ }^{35} \mathrm{Mr}$. Justice Thorson acknowledged that it might be desirable to have administrative decision makers state their reasons for the exercise of discretion, but it was not a principle of law. ${ }^{36}$ This view was re-affirmed by the Federal Court of Appeal in Canadian Arsenals Limited v. Can. Lab. Relns. Bd. ${ }^{37}$ The well known case Wrights' Can. Rope, ${ }^{38}$ while establishing that a failure to give reasons does not prevent the exercise of judicial review, also affirmed the rule that there is no obligation to give reason. ${ }^{39}$ Other cases, such as Re Ross and Board of Comm. of Police for Toronto, ${ }^{40} \operatorname{Re}$ Gill Lumber Chipman, ${ }^{41} \operatorname{Re}$ Lazar, ${ }^{42} \operatorname{Re}$ Glendenning Motorways Inc., ${ }^{43} \mathrm{Re}$ Stoangi, ${ }^{44}$ and Alkali Lake Indian Band v. Westcoast Transmission Company Ltd. ${ }^{45}$ all affirm the no obligation view.

29. Rabin, "Some Thoughts on the Relationship between Fundamental Values and Procedural Safeguards in Constitutional Right to Hearing Cases" (1978-79), 16 San Diego L. Rev. 301, at 311 .

30. Supra, n. 20, p. 79.

31. Supra, n. 5 .

32. [1978] 1 W.L.R. 1520 (Ch. D.), [1978] 3 All E.R. 211.

33. Id., p. 1531, 219.

34. [1981] I W.L.R. 754, [1981] 2 All E.R. 843.

35. [1947] I D.L.R. 501 (Ex. C1.).

36. Id., p. 535.

37. [1979] 2 F.C. 393.

38. Minister of National Revenuev. Wrights' Canadian Ropes Ltd. [1947] A.C. 109.

39. Id., p. 123.

40. [1953] O.R. 556, [1953] 3 D.L.R. 597; (Ont. H.C.).

41. Re Gill Lumber Chipman (1973) Ltd. and Unitcd Brotherhood of Carpenters and Joiners of America, Local Union 2142(1973), 42 D.L.R. (3d) 271 (N.B.C.A.).

42. Re Lazar and Assoc. of Professional Enginecrs of Manitoba (1971), 23 D.L.R. (3d) 614, [1971] 5 W.W.R. 614 (Man. Q.B.).

43. Re Glendenning Motorways and Royal Transportation Lid. (1975), 59 D.L.R. (3d) 89 (Man. C.A.).

44. Re Stoangi and Law Society of Upper Canada (No. 2) (1979), 100 D.L.R. (3d) 639 (Ont. Div. Ct.).

45. [1984] 4 W.W.R. 263 (B.C.C.A.). 
However, there is a developing line of cases which suggest that in certain circumstances an obligation to state reasons will be imposed. As stated in de Smith "(A) person prejudicially affected by a decision must be adequately notified of the case he has to meet in order to exercise any right he may have to make further representations or effectively to exercise a right of appeal." 46 Historically this approach may be traced back to the decision of the Privy Council in Wrights Canadian Ropes Ltd. v. Minister of National Revenue. ${ }^{47}$ In that case, the Minister disallowed a particular deduction but gave no reasons for his decision. The taxpayers appealed the decision. Eventually, the case came before the Privy Council. The Privy Council held that the right of appeal must "have been intended by the legislature to be an effective right." 48 The taxpayer's appeal was based upon a claim that the Minister was exercising his power in an arbitrary and unreasonable way. The Privy Council held that, although there was no legal obligation upon the Minister to state his reasons, the failure to do so could not protect a decision from review. The court could examine the facts which were before the Minister to determine if there was sufficient evidence to support his conclusions. Thus the case established two basic principles:

1. A statutorily-granted supervisory review power (right of appeal) implies a duty upon the Court to ensure that the right remains effective.

2. The failure to state reasons will not prevent a Court from exercising a supervisory power.

The second principle had been adopted in Canada. ${ }^{49}$ Yet it is the first principle which is of more interest. If the Court has a duty to ensure an effective right of review is maintained, may it, in order to enforce that right, order reasons to be given? There is some current English and Canadian authority to support this view.

In the case of Norton Tool Co. Ltd. v. Tewson, ${ }^{50}$ Sir John Donaldson (as he then was), sitting as President of the National Industrial Relations Court, applied this first principle. In Tewson, an industrial tribunal had awarded damages for unfair dismissal. The tribunal gave reasons for its decision. The employer appealed the amount of compensation to the $\mathrm{Na}$ tional Industrial Relations Court. The employee cross-appealed claiming the amount awarded was too low. Sir John Donaldson stated, with respect to the statutory appeal power: ${ }^{51}$

Our Jurisdiction is limited to a consideration of questions of law . . . If an appellant is to succeed, he must satisfy this court that the tribunal has erred in principle. But it is a corollary of the discretion conferred upon the tribunals that it is their duty to set out their reasoning in sufficient detail to show the principles upon which they have proceeded... Were it otherwise the parties would in effect be deprived of their right of appeal on questions of law.

46. De Smith, supra, n. 5, p. 149.

47. Supra, n. 38.

48. Id., at 122 .

49. D. Mullan, Administrative Law (1979, 2nd ed.), par. 120, n. 81.

50. [1973] 1 W.L.R. 45, [1973] 1 All E.R. 183.

51. Id., at 49 (W.L.R.); p. 187 (All E.R.). 
Sir John Donaldson reiterated his views in Alexander Machinery (Dudley) Ltd. v. Crabtree wherein he stated that tribunals must provide both parties with sufficient materials to enable them to know that the tribunal has not erred in law in reaching its findings of fact. ${ }^{52}$ This view has subsequently been followed by the Court of Appeal in Regina v. Immigration Appeal Tribunal Ex parte Khan (Mahmud). ${ }^{53}$ Although Chief Justice Lord Lane did qualify his support for the proposition put forward by Sir John Donaldson, ${ }^{54}$ he did state that an "appellant is entitled to know the basis of fact upon which the conclusion has been reached." $" 55$

The view expressed by Sir John Donaldson has recently been adopted in two Canadian cases, Re R.D.R. Construction Ltd. and Rent Review Commission ${ }^{56}$ and $R e$ Yarmouth Housing and Rent Review Commission. ${ }^{57}$ In both cases, the Nova Scotia Court of Appeal referred to Norton Tool Co. Ltd. v. Tewson and found an implied duty to give reasons both on the part of residential tenancy of ficer and on the Rent Review Commission when hearing appeals from a decision of the officer. "The applicant is entitled to know on what grounds his appeal has been rejected and where, in the opinion of the commission, he has gone wrong', ${ }^{58}$ The Court of Appeal in both cases was exercising an appellate power granted to it by the Rent Review Act. ${ }^{59}$ Two recent New Zealand cases have also adopted the view that natural justice may require the giving of reasons. ${ }^{60}$ In both cases Norton Tools Co. Ltd. v. Tewson was relied upon.

This view of the obligation to give reasons in order to ensure that the affected parties adequately know the case against them has been recently affirmed by the two members of the Supreme Court of Canada. In Blanchard v. Control Data Canada Ltd., ${ }^{61}$ Lamer J., speaking for himself and MacIntyre J.62 held that where a reason's obligation is imposed by a statute ${ }^{63}$ then the reasons given must be adequate. The reasons

52. [1974] I.C.R. 120, p. 122 (N.1.R.C.).

53. [1983] 2 W.L.R. 759.

54. "Speaking for myself, I would not go so far as to endorse the proposition set forth by Sir John Donaldson that any failure to give reasons means a denial of justice and is itself an error of law," Id., at 762.

S5. Id., at 763.

56. (1983) 139 D.L.R. (3d) 168 (N.S.C.A.).

57. (1983) 139 D.L.R. (3d) 544 (N.S.C.A.).

58. Id., at 555 .

59. S.N.S. 1975 , c. 56, Sec. $27(1)$ which provides an appeal to the Appeal Division of the Supreme Court on questions of jurisdiction of law; Sec. 29(1) allows the Commission to stte a case to the Appeal Division of the Supreme Court on questions of law.

60. Eastern (Auckland) Rugby Football Club (Inc.)v. Licensing Control Commission, [1979] 1 N.Z.L.R. 367 65; Bartonv. Licensing Control Commission, [1982] I N.Z.L.R. 31.

61. (1985) 14 D.L.R. (4th) 289.

62. Beetz J. wrote the majority judgment (concurred with by Chouinard and Wilson JJ.). He accepted the view of Monet J.A. (dissenting in the Court of Appeal, [1983] Que. C.A. 129) that "sufficient reasons were given for the arbitral award" (p. 297). Lamer J. wrote a separate judgment concurring in result.

63. The Act respecting Labour Standards, R.S.Q. 1977 c. N-1.1 (1979 (Que.), c. 45) s. 129: The arbitration award must state the grounds on which it is based and be rendered in writing. 
must be intelligible and the parties must be able to understand the basis for the decision. ${ }^{64}$ Reasons which do not meet this standard are insufficient and amount to a denial of natural justice. Thus the case appears to support the view that the failure to provide adequate reasons may be a denial of natural justice. However, it should be pointed out that in this case the obligation to give reasons was statutorily imposed.

The approach in Norton Tools Co. is of interest for two reasons: First, it suggests an exception to the general "no duty" rule. The exception arises whenever there is a statutory right of appeal or possibly a simple power to reconsider. It is consistent with the values served by a reason's requirement in that it assists all three entities, the interested party, the decision-maker and the courts to make better decisions. The scope of the exception is still uncertain. For example, is it relevant whether the decision can be appealed by way of hearing de novo? In both Nova Scotia cases the appeal from the decision of the officer of the commission was a review of proceedings only. It may be that where the appeal is a complete rehearing such that any procedural defects at the first can be cured at the second, then no reasons need be given at the first level. ${ }^{65}$

The other interesting point raised by these cases is the potential breadth of the exception. It may become all encompassing. It may be possible to argue that if the duty to give reason is premised upon maintaining an effective right of appeal, then the duty should arise whenever a statutory decision-maker is subject to supervisory review by the courts - in other words a general right to reasons. The argument is as follows. A right to reasons exists whenever a right of appeal is provided for. A right of appeal is generally permitted for questions of law and jurisdiction or questions of jurisdiction only. Its scope is then equivalent to that exercised by the courts pursuant to judicial review. Thus an effective right of appeal on questions of jurisdiction means an effective right of judicial review. Thus if the court will order reasons in order to ensure all issues of jurisdiction are properly dealt with it should not depend upon whether the review arises by way of appeal or judicial review.

Suppose the appeal provision also permits appeals on questions of law. Questions of law are reviewable by the courts pursuant to review for errors of law on the face of the record. Review for error of law on the face of the record will generally not be useful unless the tribunal has given reasons. ${ }^{66}$ If a court is willing to order reasons to be given in order to ensure an effective right of appeal, those reasons will form part of the record ${ }^{67}$ and thus be available for review by way of judicial review. In short, all errors which are reviewable by way of appeal are reviewable by judicial review. If a court is willing to order reasons in order to ensure an effective exercise of appellate supervisory review, then a court is also en-

64. Supra, n. 61 at 308.

65. This argument was advanced in Osmond v. Public Service Board of New South Wales, [1983] 1 N.S.W.L.R. 691 (Adm. Law Division) (on appeal to the Court of Appeal) but was rejected. The Court held that the common law had not yet developed to the stage where it can be said that there is an obligation upon administrative tribunals to supply reasons in the absence of an express statutory requirement.

66. De Smith, supra, n. 5 at 134-139, 148-151.

67. Supra, n. 17. 
suring a more effective use of judicial review. Why then limit the rule to appeals? Why not establish the rule that reasons are required in order to ensure an effective exercise of the court's supervisory review powers, both statutory and inherent.

Before discussing the next topic, "fairness and reasons," it should be pointed out that the failure to state reasons will not necessarily prevent the courts from exercising a supervisory review power ${ }^{68}$ If the basis of an application for judicial review or appeal is that a tribunal exceeded its jurisdiction or otherwise acted ultra-vires, for example by failing to consider relevant matters or taking into account irrelevant matters, the application for review (or appeal) may still be successful even without the aid of reasons. However it is may be more difficult to prove such allegations when reasons are not given. As a result it is probably true to say that if a reasons requirement were established, an increase in the number of applications for judicial review might occur (a matter which appears to have concerned the courts) ${ }^{69}$ However, it is equally true to suggest that the process of producing written reasons may result in a more considered and well thought out decision, thus lessening the likelihood of any successful challenge and ultimately the likelihood of any challenge at all.

\section{B. FAIRNESS AND RIGHT TO REASONS}

If natural justice does not provide a guarantee of a right to reasons, does the concept of fairness fill the gap? Implicit in the question is the assumption that fairness and natural justice are not the identical progeny of the concept of fair procedure. If fairness and natural justice are twins, then there may be no need to treat the two concepts separately. Indeed, the same justification for a reasons requirement applies to both. However, it is not entirely clear whether natural justice and fairness are identical twins or merely fraternal concepts with distinct and separate identities within the framework of fair procedure generally.

In Canada, the relationship between natural justice and fairness remains uncertain. In Nicholson, Chief Justice Laskin's judgment contains allusions which support either view. ${ }^{70}$ Subsequently, in Martineau \#2,71 Mr. Justice Dickson (as he then was), speaking for three members of the court, ${ }^{72}$ suggested that ${ }^{73}$

it is wrong, in my view, to regard natural justice and fairness as distinct and separate standards and to seek to define the procedural content of each . . . The content of the principles of natural justice and fairness in application to the individual cases will vary according to the circumstances of each case. . .

Yet, regardless of the approach, it is clear that the concept of fairness has expanded the traditional reach of the doctrine of fair procedure so as

68. Wrights Canadian Rope, supra, n. 35; Re Ross, supra, n. 40; Alkali Lake Indian Band, supra, n. 45.

69. See comments of Vice-Chancellor Megarry in McInnes v. Onslow Fane, supra, n. 32 at 223; 1535.

70. Re Nicholson and Haldimand-Norfolk Regional Board of Commissioners of Police [1979] I S.C.R. 311, 88 D.L.R. (3d) 671.

71. Martineau v. Matsqui Institution Disciplinary Board (No. 2) [1980] I S.C.R. 602, 106 D.L.R. (3d) 385.

72. Laskin C.J. and McIntyre J. concurred with Dickson J.

73. Supra, n. 71 at 630 (S.C.R.), 411 (D.L.R.). 
to encompass the so-called "administrative" decision makers. In so doing, has the doctrine also created a right to reasons?

It is possible, of course, to justify a reasons requirement to fairness upon the same basis as natural justice: as a duty to give reasons in order to ensure an effective exercise of the right to appeal. ${ }^{74}$ If one is willing to adopt the "appeal" justification, it applies to fairness whether or not fairness is seen as being a synonym to natural justice. However, the fairness cases also appear to be able to support a more limited, modified right to reasons - a right to know the grounds upon which a decision has been made. Grounds would differ from reasons in that grounds would simply indicate the conclusion reached without giving any of the necessary facts or reasoning process followed. Reasons, on the other hand, should indicate both the necessary facts found and the logical reasoning process adopted.

In Nicholson, Chief Justice Laskin states that "the appellant should have been told why his services were no longer required and given an opportunity, whether orally or in writing as the Board might determine, to respond." 75 In subsequent fairness cases, lower courts have adopted a similar approach, imposing a requirement that the person affected by the decision be told why a particular decision is being considered. For example in Culhane v. A.G. of British Columbia and Harrison, ${ }^{76}$ Culhane sought to obtain reasons for the revocation of her licence to visit prisoners held in provincial institutions. Mr. Justice Lambert, in dissent, held that Culhane was entitled to be informed of the general nature of the allegations of facts and to be given an opportunity to respond. The majority did not agree with Lambert, J. and held that in any event the court should not exercise its discretion to grant relief in favour of Culhane. In McCarthy v. Calgary Roman Catholic Separate School District \#1 Board of Trustees 77 the court held that it was unfair for the Board to ask McCarthy to resign from his position as Superintendent of the Board without having told him the grounds for the request and giving him an opportunity to respond. Similar views were expressed by the Ontario Divisional Court in Re Petersen and Atkinson. ${ }^{78}$ Interestingly, a similar approach to fairness and the requirement for grounds in advance has occurred in New Zealand. In Smitty's Industries Ltd. v. Attorney-General ${ }^{79} \mathrm{Mr}$. Justice Vautier imposed an obligation upon the National Roads Board to give advance notice of the criteria by which applications for a licence to operate a mobile shop would be judged.

These cases suggest the development of a common law rule that disclosure of the grounds for a decision, the "gist" of the reasons, be given in advance. In each case, the grounds for the decision-maker's action were required to be given in the form of notice to the affected person. Thus, although the cases can and do support the proposition that

74. T. Flexman Lid. v. Franklin County Counci] [1979] 2 N.Z.L.R. 690 (S.C.).

75. Supra, n. 70 at 328 (S.C.R.), 682 (D.L.R.).

76. (1980) 108 D.L.R. (3d) 648 (B.C.C.A.).

77. [1980] 4 W.W.R. 738 (Alta. Q.B.).

78. (1979) 95 D.L.R. (3d) 349.

79. [1980] I N.Z.L.R. 355 (S.C.). 
proper notice is required before a decision can be made, the cases also establish a requirement of notification of the proposed or intended grounds for the decision. Presumably, after notice is given and an opportunity to respond is provided, any decision made must be on the basis of the grounds stated. Otherwise the person affected will have been misled and thus denied procedural fairness. To the certain extent, this notification of grounds' requirement has been statutorily recognized in Ontario. Under section 8 of the Statutory Powers Procedure Act, ${ }^{80}$ whenever the good character, propriety of conduct or competence of a party is in issue in any proceedings, the party is entitled to be furnished prior to the hearings with reasonable information of any allegation with respect thereto. The fairness cases appear to go a bit further than section 8 in that the cases suggest that reasons why a decision-maker intends to act in a certain way must be disclosed whereas section 8 does not appear to limit the decision-makers' power to decide to only those issues raised by the notice given pursuant to section 8 .

Although the argument for a grounds requirement derives from the recent fairness cases, there is some 19th century precedent to support a grounds rule. In a series of cases involving the Wine and Beerhouse Act of 1869, the Queen's Bench Division of the English Courts developed a grounds rule. ${ }^{81}$ The justification for the rule appeared to be premised not upon issues of fair procedure but upon a theory of jurisdiction. Under the Act, the power to refuse a liquor licence was limited to four specific grounds. The court held that decision-makers were required to state their grounds for refusal in order to "justify their decision and show that they were acting within their jurisdiction" 82 There are also some Australian cases which follow the approach of these cases and develop a "grounds" rule as a means of demonstrating jurisdiction. ${ }^{83}$ As indicated by Ackhurst in his article ${ }^{84}$ the extent to which these cases reflect a general principle is uncertain, given that the decisions appear limited to the particular statutes in question. However the cases do illustrate the power of the courts to expand the common law and to develop a judicially created reasons requirement.

\section{THE CHARTER OF RIGHTS}

Section 7 of the Charter of Rights and Freedoms ${ }^{85}$ provides that Everyone has the right to life, liberty and security of the person and the right not to be deprived thereof except in accordance with the principles of fundamental justice.

In Singh v. Minister of Employment and Immigration, ${ }^{86}$ Wilson J., speaking for herself and two other members of the Court, ${ }^{87}$ accepted that

80. Supra, n. 22.

81. Supra, n. 3 .

82. R.v. Sykes, supra n. 3 at 53-54 (p. 53).

83. Giris Pty. Ltd. v. Commissioner of Taxation of the Commonwealth of Australia (1969-70) 119 C.L.R. 365; Federal Comm. of Taxation v. Brian Hatch Timber Co. (Sales) Pty. Ltd. (1972) 128 C.L.R. 28; Kolotex Hosiery (Australia) Pty. Ltd. v. Comm. of Taxation (1975) 49 A.L.J.R. 35; for a discussion of these cases, see Flick, supra n. 5 at 93-94.

84. Akehurst, supran. 5.

85. Constitution Act, 1982, as enacted by Canada Act 1982 (U.K.), c. 11.

86. (1985) 58 N.R. 1.

87. Dickson C.J. and Lamer J. Beetz J., speaking for himself and Estey and McIntyre JJ., decided the case without relying on the Charter. 
"at a minimum the concept of fundamental justice as it appears in section 7 of the Charter includes the notion of procedural fairness articulated by Fauteux C.J. in Duke v. The Queen." 88 Thus, it would appear that the principles of natural justice have been constitutionalized. ${ }^{89}$ It is submitted that if the right to reasons does not presently form part of the common law, the use of the term "principles of fundamental justice" in section 7 may have provided an opportunity to constitutionalize the right to reasons. However, before discussing this point further, two ancillary matters concerning section 7 should be clarified.

First, the section only applies to those situations which involve the right to life, liberty and security of person and a denial thereof. ${ }^{90}$ Unless the terms "life, liberty and security of person" are given a broad interpretation to include those interests which are necessary to protect basic human dignity (for example, pension and welfare rights ${ }^{91}$ or right of one's reputation) $^{92}$ it is unlikely to govern the conduct of most administrative decision makers. ${ }^{93}$ However, certain statutory decisionmakers do make decisions which have the potential of restricting one's liberty. For example, those entities which make decisions regarding the disciplining of prisoners, ${ }^{94}$ entitlement to parole, ${ }^{95}$ extradition, ${ }^{96}$ and immigration ${ }^{97}$ have all been subject to court proceedings in which section 7 has been argued. The courts have accepted that section 7 may apply to these decision-makers.

A second point which should be mentioned in regard to section 7 is the ongoing debate on whether section 7 is limited in its application to only procedural matters or may it apply to issues of substantive fairness. ${ }^{98}$ The

88. Supran. 86 at 62.

89. Subject, of course, to section 1 (such reasonable limits prescribed by law as can be demonstrably justified in a free and democratic society) and section 33 (the legislative override).

90. In Operation Dismantle Inc. v. The Queen (1985) 59 N.R. 1, Wilson J. adverted to the debate on whether section 7 gives rise to two separate rights (the right to life, liberty and security of the person and the right not to be deprived thereof except in accordance with the principles of fundamental justice) or one unequivocal right (the right not to be deprived of life, liberty or security of the person except in accordance with the principles of natural justice).

91. B. Schwartz, "The Charter and Due Process" in Isaac Pitblado Lectures In Advocacy $1983,31$.

92. Joplin v. Chief Constable of the City of Vancouver Police Department (1983) 144 D.L.R. (3d) 285; affd. (1985) 61 B.C.L.R. 396 (B.C.C.A.).

93. For a perceptive and stimulating review of the interpretation of section 7 on this question and on the "procedural versus substantive review" debate, see J. Whyte, "Fundamental Justice: The Scope and Application of Section 7 of the Charter" (1983) 13 Man. L.J. 453.

94. Re Soenen and Thomas (1984) 3 D.L.R. (4th) 658 (Alta. Q.B.) (decision of a director of correctional institution re institutional rules); Re Howard and Presiding Officer of Inmate Disciplinary Court of Stony Mountain Institution, (1984) 4 D.L.R. (4th) 147 (F.C.T.D.) (right of inmates to be represented by counsel at a disciplinary hearing).

95. R. v. Cadeddu, (1983) 40 O.R. (2d) 128 (Ont. H. Ct.) Appeal abated (1983) 41 O.R. 481. (Provincial parole board's revocation of parole without a hearing); Re Lowe and the Queen (1983), 5 C.C.C. (3d) 535 (B.C.S.C.) (same as Cadeddu); Re Mason and the Queen (1983), 43 O.R. 321 (Ont. H.C.) (right to an in-person post-suspension hearing).

96. Re United States of America and Smith (1984) 7 D.L.R. (4th) 12 (Ont. C.A.) (the use of affidavit evidence in extradition hearings).

97. Re Singh and Minister of Employment and Immigration, supra, n. 86 (right to an oral hearing on matters involving redetermination of refugee status).

98. See Whyte, supra, n. 94. 
case authority on this issue is split ${ }^{99}$ and the Supreme Court has yet to rule on the matter. ${ }^{100}$ For the purposes of this article, the resolution of this debate is not determinative. Even if section 7 is limited to matters of procedure, the question still arises: does section 7 guarantee a right to reasons?

The answer to this question involves a consideration of the language of the section. The section speaks of neither natural justice nor fair procedure; instead the term "principles of fundamental justice" is used. In the Special Joint Committee of the Senate and House of Commons which reviewed the proposed Resolution intended to be sent to Britain, Mr. Barry Strayer, who was at that time the Assistant Deputy Minister of Public Law in the Department of Justice, stated the Justice Department's view of section $7 .{ }^{101}$

\footnotetext{
... it was our belief that the words "fundamental justice" would cover the same thing as what is called procedural due process, that is the meaning of due process in relation to requiring fair procedure.
}

The basis for this belief stems from the use of the term "fundamental justice" in section 2(e) of the Canadian Bill of Rights. ${ }^{102}$ In discussing the meaning of the term fundamental justice in sec. 2(e), Chief Justice Fauteux said:103
Without attempting to formulate any final definition of those words ["a fair hearing in accordance with principles of fundamental justice'], I would take them to mean, generally, that the tribunal which ajudicates upon [a person's] rights must act fairly, in good faith, without bias and in a judicial temper, and must give to him the opportunity adequately to state his case.

This definition is very similar if not identical to a definition of procedural fairness or natural justice. Thus if "fundamental justice" is merely a synonym for procedural fairness then no new basis for a right to reasons has been established by the enactment of section 7 . The right to reasons argument stands or falls upon establishing a right to reasons as an aspect of procedural fairness. However, if principles of fundamental justice is a broader concept than natural justice or fairness, a stronger argument for a right to reasons may exist.

Is the principle of fundamental justice broader than our current common law concept of fair procedure? Chief Justice Fauteux in his definition in Duke was careful to indicate that he was not "attempting to formulate any final definition". Certainly, if section 7 is found to contain a

99. Some of the cases which have discussed the issue are Reference re Section 94(2) of the Motor Vehicle Act (1983), 147 D.L.R. (3d) 539 (B.C.C.A. - substantive); R. v. Randall (1984) I D.L.R. (4th) 722 (N.S.C.A. - procedural); R. v. Hayden (1984), 3 D.L.R. (4th) 361 (Man. C.A. - procedural); Re Mason and the Queen, supra n. 95.

100. The Supreme Court held in Reference Re Section 94(2) of the Motor Vehicle Act (Unreported, Dec. 17, 1985) that principles of fundamental justice are found in the basic tenets and principles of our legal system and are not limited to procedural matters.

101. Minutes of Proceedings and Evidence of the Special Joint Committee of the Senate and the House of Commons on the Constitution of Canada Issue No. 40 (Tuesday, January 27, 1981) at 46: 32 .

102. R.S.C. 1970 Appendix III, as amended by 1970-71-72 c. 38 , s. 29 , section 2 (e) . . no law of Canada shall be construed or applied so as to . . . deprive a person of a right to a fair hearing in accordance with the principles of fundamental justice for the determination of his rights and obligations.

103. Duke v. The Queen [1972] S.C.R. 917 at 923, 28 D.L.R. (3d) 129 at 134. 
substantive fairness component, then it is broader. Some judges have indicated that section merely establishes a concept of natural justice with no extended meaning. ${ }^{104}$ However, in Re Potma v. The Queen, ${ }^{105}$ the Ontario Court of Appeal expressed the view that ${ }^{106}$

\footnotetext{
"Fundamental justice", like "natural justice" or "fair play", is a compendious expres. sion intended to guarantee the basic right of citizens in a free and democratic society to a fair procedure. The principles or standards of fairness essential to the attainment of fundamental justice are in no sense static, and will continue as they have in the past to evolve and develop in response to society's changing perception of what is arbitrary, unfair or unjust.
}

Thus there is a recognition that the concept of fair procedure which is contained within the term "principles of fundamental justice" may be broader than the common law principle of fair procedure. The Court of Appeal accepted that section 7 hasn't frozen into place only those concepts which now form part of our interpretation of natural justice. In at least one area, parole revocation, the courts have clearly found that section 7 encompasses procedural obligations which would not otherwise be required by common law or statute. In Regina v. Cadeddu ${ }^{107} \mathrm{Mr}$. Justice Potts of the Ontario High Court held that a revocation of parole without an in person hearing, although not a violation of the statutory requirement of the Parole Act ${ }^{108}$ or of the common law concepts of fair procedure, was a violation of the principles of fundamental justice enshrined in our constitution pursuant to section 7. This view has been followed in a number of cases. ${ }^{109}$ The Ontario Parole Board has altered its practice so as to provide the apprehended inmate an opportunity for a hearing in each case. ${ }^{110}$

If the approach adopted in Caddedu is followed, then it is clear that section 7 may provide greater protection than currently provided for by the common law. If so, one area of the common law of fair procedure which has been clearly seen to contain a gap (the failure of right to require reasons) may be rectified. Section 7 could fill the gap. As stated by Prof. Mullen the requirement to give reason for a decision is the only way to ensure that the decision-maker is "hearing" the case. ${ }^{111}$ If the courts were reluctant in the past to break from the traditional view of natural justice in order to establish a reasons argument, that reluctance can now

104. Re Howard and Presiding Officer of Inmate Disciplinary Court of Stony Mountain Institution, supra, note 95, at p. 158 wherein Nitikman J. referred to the fact that the Charter was not passed in a legal vacuum.

105. (1983), 41 O.R. (2d) 43; leave to appeal to Supreme Court of Canada refused, 17 May 1983.

106. Id., at 52 (emphasis added).

107. Supra, n. 96.

108. R.S.C. 1970, c. P-2, as amended S.C. 1976-77, c. 53, s. 22.

109. Re Lowe and the Queen, supra, n. 96; Re Mason and the Queen, supra, n. 96; Re Martens and the Queen (1983), 8 C.C.C. (3d) 336 (B.C.S.C.); Re Dumoulin and the Queen (1983), 6 C.C.C. (3d) 190 (Ont. H. Ct.).

110. See comments of Smith J. in Dumoulin, supra, n. 109 at 191.

111. "Unfairness in the Administrative Process - The Impact of Nicholson and the Charter of Rights"' (1983) Pitblado Lectures 68, 76. 
be overcome by use of section 7 which permits the development of a fair procedure in order to prevent unfair or unjust actions. ${ }^{111 \mathrm{~A}}$

\section{STATUTORY REQUIREMENTS}

\section{A. TWO APPROACHES}

The arguments advanced earlier to support a "right to reasons" requirement suggest that the concept of a right to reason has yet to be firmly accepted by the courts. As an alternative to the advancement of the law by judicial decision making, the enactment of a statutory provision requiring the giving of reasons has been adopted in a number of jurisdictions. ${ }^{112}$ This route although providing a more effective means of ensuring a right to reasons, also has certain disadvantages. For example, the existence of a statutory rule may lead the courts to infer the absence of a common-law rule. ${ }^{113}$ Further, the focus of the argument may shift from a discussion of the purposes of reasons to one of whether the particular tribunal in question comes within the exact terms of the statute. ${ }^{114}$ However, as indicated such an approach does ensure that those decisions which do fall within the scope of the particular act must be supported by reasons.

There is no generally accepted statutory method by which a "right to reason" requirement is to be stated. In Canada, two alternate routes have been developed. One method is to prescribe in a general "administrative procedures" statute that reasons must be given. This route has been adopted in both Ontario and Alberta. Section 7 of the Alberta Administrative Procedures Act ${ }^{115}$ provides as follows:

Where an authority exercises a statutory power so as to adversely affect the rights of a party, the authority shall furnish to each party a written statement of the decision setting out

a) the findings of fact upon which it based its decision, and

b) the reasons for the decision.

However, the Act only applies to those authorities that have been so designated by the Lieutenant Governor in Council. Eleven such authorities have been designated. ${ }^{116}$ Section 7 applies to all eleven boards although with respect to the Alberta Assessment Appeal Board the section only applies if a party to an appeal so requests.

111A. In D\&H Holdings Ltd. v. Vancouver and Armstrong (1985), 64 B.C.L.R. 102 (B.C.S.C.) it was held that a statutory provision (s. 275 of the Vancouver Charter) which expressly permits the Vancouver City Council to "grant, refuse, revoke or suspend" a business licence "without stating any reason therefor" violated section 7 of the Charter as being contrary to "principles of fundamental justice".

112. Supra, n. 22.

113. Stoangi and Law Society of Upper Canada, supra, n. 44.

114. For example, the meaning of the term "decision" in section 13(1) of the Administrative Decisions (Judicial Review) Act 1977 (defined as a decision of an administrative character made, proposed to be made, or required to be made, as the case may be (whether in the exercise of a discretion or not) under an enactment, other than a decision by the GovernorGeneral or a decision included in any of the classes of decisions set out in Schedule 1), see Burns v. Australian National University (1981-82) 40 A.L.R. 707, reversed on apeal (1982), 43 A.L.R. 25.

115. R.S.A., 1980 c. A-2.

116. Alta. Reg. $135 / 80$. 
Ontario adopted a general reasons requirement in its 1971 Statutory Powers Procedure Act. ${ }^{117}$ Under section 17 "a tribunal shall give its final decision and order, if any, in any proceedings in writing and shall give reasons in writing therefor if requested by a party". The Act applies to those tribunals which in the exercise of a statutory power of decision conferred by or under an Act of the Legislature, are required by or under such Act or otherwise by law to hold or to afford to the parties to the proceedings an opportunity for a hearing before making a decision. ${ }^{118}$ Thus the reasons requirement is limited in two ways. First, the tribunal must be under an obligation to give a hearing and secondly there must be a request for reasons.

The second approach for a statutory reason requirement is a tribunalspecific approach. This is, the requirement for reasons is determined upon a tribunal-by-tribunal basis. Under this method whenever a statute creates a tribunal, the statute will provide (when the legislators consider it appropriate) that the tribunal shall state the reasons for their decisions. ${ }^{119}$ Alternatively, the legislature may leave it up to the tribunal to decide whether to give reasons. ${ }^{120}$ The advantage to this approach is that the reasons requirement can be tailored to the specific tribunal in question. If for example, the tribunal deals with matter of national security or information of a confidential nature, then a provision excluding reasons when such issues arise could be provided for.

The first method outlined, the general approach, has been adopted in other Commonwealth jurisdictions. Both the United Kingdom and Australia have enacted a general reasons requirement. In the United Kingdom the requirement is found in section 12 of the Tribunal and Inquiries Act, 1971. ${ }^{121}$ Section 12 requires those tribunals listed in schedule 1 of the Act to provide reasons for their decisions upon request. Certain exceptions are provided for; matters of national security, ${ }^{122}$ where the person requesting reasons is not primarily concerned with the decision and the decision-maker is of the opinion that it would be contrary to the interests of any person primarily concerned, ${ }^{123}$ and decisions of a Minister in connection with the preparation, making, approval, confirmation or concurrence in regulations or scheme of a legislative and not executive character. ${ }^{124}$ Further, the Lord Chancellor or the Secretary of State, upon consultation with the Council of Tribunals, may exclude such decisions which by their subject matter or the circumstances in which they are made makes the giving of reasons unnecessary or impracticable. ${ }^{125}$ The Council has, as a general rule, opposed any attempt to

117. Supra, n. 22.

118. Id., s. 3.

119. For example, Immigration Act, 1976, S.C. 1976-77, c. 52, s. 65(3).

120. Public Service Staff Relations Board Regulations and Rules of Procedure, C.R.C. 1978, c. 1353, s. 86. For a discussion of the value of board created rules and practices see $H$. Janisch, "The New General Rules of The Canadian Transport Commission" (1983), I Ad$\min$. L.R. 173.

121. Supra, n. 22.

122. Id., s. 12(2).

123. Id., s. 12(2).

124. Id., s. 12(4).

125. Id., s. 12(6). 
derogate from a reasons requirement. In its first report, the Council discussed whether certain specific tribunals ought to be exempted from a reasons requirement. ${ }^{126}$ The Council felt that an obligation to provide reasons should apply even though in many cases such reasons might amount to no more than a statement on the tribunal's belief in the truth or sincerity of an applicant or that the tribunal's decision was one based upon its own knowledge and experience. ${ }^{127}$ In one case the Council agreed to the exemption primarily on the basis that the tribunals in question were already subject to a reasons requirement pursuant to a specific statutory provision. ${ }^{128}$ Recently, the Council has commented upon a trend by the government to shift from a general reasons requirement to one of reasons upon request. In 1981-82, the Council was asked to reply to a proposal that reasons of the Rent Assessment Committees be provided only upon request. The Council commented upon the value of reasons $^{129}$ and resisted the proposal. ${ }^{130}$ In $1982-83$, the Council was again consulted about a similar proposal for two other tribunals, ${ }^{131}$ which the Council again rejected. The Council's approach emphasizes the importance, in their view, of an unrestricted reasons requirement. Although section 12(1) of the Tribunal and Inquiries Act, 1971 only specifies reasons upon request, the Council's policy is to require that procedural rules for particular tribunals should incorporate an unqualified duty to give reasons. ${ }^{132}$

The Australian approach is somewhat similar. ${ }^{133}$ Under the Administrative Decisions (Judicial Review) Act, 1977, a person aggrieved by a decision (as defined in the Act) may request reasons. ${ }^{134}$ Under the Act, reasons must include the setting out of the findings on material questions of fact, referring to the evidence or other materials on which those findings are based. ${ }^{135}$ Like the United Kingdom legislation, the act only applies to certain types of decisions, ${ }^{136}$ and further, only some of these are

126. Annual Report of the Council on Tribunals for 1959, paras. 58-69.

127. Id., paras. 66-68 (in reference to the Conscientious Objectors Tribunal and the Agricultural Arbitrators).

128. Id., paras. 61-63. This was in reference to certain Inland Revenue Tribunals. There was, however, one Inland Revenue Tribunal, (the Board of Referees in cases submitted by the Special Commissioners for determination under sec. 251 of the Income Tax Act, 1952), which was not subject to a reasons requirement and yet the Council agreed to an exception. The Council viewed this tribunal as one which simply decided whether further proceedings should be taken but did not determine the tax-payer's rights.

129. The Annual Report of the Council on Tribunals for 1981-82, paras. 3.37. The values recognized included:

(i) it helps the parties to understand the decision and contributes to the openness and fairness of the decision and proceedings;

(ii) it encourages a high standard of decision-making and consistency of decisions; and

(iii) it enables the parties to give proper consideration to the possibility of taking the case to the High Court.

130. Id., par. 3.37. The proposal was subsequently implemented by legislation.

131. The Annual Report of the Council on Tribunals for 1982-83, paras. 2.6-2.9.

132. H.W.R. Wade, Administrative Law, supra, n. 5, at 813.

133. For a more complete discussion of the Australian approach see R. Burnett, "The Giving of Reasons" (1983), 14 Fed. L. Rev. 157.

134. Supra, n. 22, s. 13.

135. Id., s. 13(1).

136. Id., Schedule I. 
subject to a reasons requirement. ${ }^{137}$ Also, there are provisions which permit certain information to be withheld, such as information that relates to the personal affairs or business affairs of a person, other than the person making the request and the information was supplied in confidence or would reveal a trade secret; ${ }^{138}$ information which relates to the security, defence or international relations in Australia and disclosure would not be in the public interest; ${ }^{139}$ or the information would involve the disclosure of deliberations of Cabinet and would be contrary to the public interest. ${ }^{140}$

\section{B. SOME PROBLEMS}

Thus it is clear that the concept of a statutory "right to reasons" has been adopted as a means to fill the gap left by the common law. Although the statutory provisions are not identical, several common concerns arise and have to be considered. Three basic matters need to be addressed. First, which type of decisions (or tribunals) should be subject to a reasons requirement? Second, if a decision-maker is subject to a reasons requirement, should there be exceptions in particular circumstances? If so, when? Third, should the requirement to give reasons be dependent upon a request for the reasons? If so, a request by whom? I should like to address each of these concerns in turn.

The major question which arises when considering enacting a statutory right to reasons is the determination of those situations in which such a requirement ought to be imposed. Are there certain types of decisions or decision makers which ought not to be subject to a reasons requirement? The common law development appears to be concerned with providing reasons when judicial or quasi-judicial decisions are being made, a natural enough phenomenon given the traditional view of natural justice. The focus would appear to be on decisions which are individual specific, involving determinations of fact and the application of pre-determined principles to particular cases. ${ }^{141}$ The fairness cases, which require an "early-warning" system, all involved situations in which an individual's livelihood or reputation was at stake, again suggesting individual specific decisions. The Charter argument, based on section seven, requires a threat to a person's life, liberty or security. The statutory models also attempt to limit the application of the rule. Most do this simply by providing a list of decision-makers to which the act applies. The Ontario statute limits its application to those tribunals which are required to give a hearing, suggesting a judicial or quasi-judicial type of tribunal. Accepting that the judicial, (or quasi-judicial) tribunal ought to give reasons,

137. Id., Schedule 2, Some of the exceptions appear to be reasonable, for example, decisions relating to the administration of criminal justice (for example, the issuances of a search warrant or the summoning of witnesses) and decisions relating to the institution of proceedings in a civil court. Others are not so clear, for example, decisions relating to personnel management of the Armed Services or Public Service or a decision in connection with redress of grievances in the Defence Forces.

138. Id., s. $13 \mathrm{~A}(1)$.

139. Id., s. 14(1)(a).

140. Id., s. 14(1)(b).

141. D. Mullan, supra, n. 111 , at $68,79-82$. 
should the requirement be extended to cover other statutory decisionmakers? For example, should the C.R.T.C. be subject to a reasons requirement when it decides issues involving Canadian content on T.V.? If so, at what stage? When the policy of Canadian content is being defined or when it is being applied? What about decisions in which the public is invited to participate, for example land-use planning? Should a requirement of reason be imposed?

In David Mullan's seminal article Fairness: The New Natural Justice, he refers to a spectrum of decision-making functions - straight law fact determinations with serious consequence to individuals to broad policy oriented decisions exercised typically by a Minister of the Crown - with a variable procedural fairness content. ${ }^{142}$ Should reasons follow a similar line of analysis or is the requirement so fundamental that regardless of the decision-maker's location on the spectrum, a right to reason ought to be imposed, the detail and specificity of those reasons varying with the nature of the decision? Traditionally, the policy end of the spectrum, whether it was labelled administrative or legislative, attracted little if any procedural protection. The concept of rulemaking, of exercising a legislative power, still attracts the conclusion that no procedural rights attach to the process. ${ }^{143}$ But surely the rationale and justification for reasons is not limited to the adjudicative, rights-interference model? The public acceptability of a proposed decision or rule, and the assurance of well-considered, well-reasoned decisions are still legitimate and proper goals of rule-making or policy exercising decisions. And, judicial scrutiny of such decisions is still the major means of control until notice and comment or other statutory protections are provided. Thus a requirement for reasons does have application beyond the traditional boundary of law/fact determinations. As stated by Kenneth Culp Davis in his treatise on Administrative Law “. . . (the) courts should take into account that findings and reasons are usually two of the four elements in a bundle of protections against arbitrariness - open standards, open findings, open reasons and open precedent." 144 Parliament, the supreme legislation authority, must exercise its power in public and the legislators must be prepared to explain and justify their action. Why then, should lesser legislative authorities, such as the Cabinet or other statutory tribunal exercising a rulemaking power, be freed of similar obligations - an obligation to explain, to provide a concise general statement of the basis and purpose of their decisions? ${ }^{145}$

With respect to the second major concern, if a decision-maker is subject to a reasons rule, under what circumstances should that rule be excluded? The statutory models provide generally for two types of exceptions, information of a personal or confidential nature and secondly, information the disclosure of which would be contrary to the public in-

142. (1975) 25 U. of Toronto L.J. 281 at 300.

143. Bates v. Lord Hailsham [1972] I W.L.R. 1373 (Ch. Div.); Attorney-General of Canada v. Inuit Taparisart of Canada [1980] 2 S.C.R. 735.

144. K.C. Davis, Administrative Law Treatise (second edition), Volume 3, Chap. 14, p. 123.

145. In the United States, the Administrative Procedure Act, sec. 553(c) provides that an agency which makes rules and which is not obligated to hold a hearing must still incorporate in the rules adopted a concise general statement of their basis and purpose. 
terest. The first exception appear to be concerned with ensuring that the decision-makers obtains all the relevant information. The exception generally applies to protect information being disclosed to persons who are not primarily concerned with the decision or are attempting to obtain a trade secret. Thus persons will be more willing to make full disclosure of relevant information if they know that the information will not be made available to others. The second exception also appears reasonable, ensuring that information relating to national security or possibly Cabinet deliberations will not be revealed. One concern may be whether an independent evaluation of the need for secrecy should be provided for. Should there be a requirement that all such claims must be reviewed by a senior government of ficial, for example the Attorney General or alternatively by the Courts? ${ }^{146}$

The last issue of concern appears, at first, as being a bit nit-picky. Of what significance is the distinction between an obligation to give reasons or an obligation which arises only upon a request? Yet the difference is important. First, it illustrates a different emphasis upon the value of reasons. In the first approach, reasons are seen to be a beneficial requirement in and of themselves. It emphasises the value of reasons in promoting a better administrative decision-making process. It assists in the establishment of precedent and may provide assistance to future persons. The "upon request" route suggests that the value of reasons simply lies with the party affected. It hinders the development of precedent by producing a haphazard record of the decision-making process, possibly only emphasizing the errors which the decision-maker makes. Further, the request approach may subconsciously influence the decision-maker's decision in that negative decisions (decision in which an applicant is refused permission) are more likely to be challenged and thus a request for reasons made. Thus a decision-maker may prefer to adopt a less confrontational route and allow an application. The decision-making scheme may become skewed. The United Kingdom's Council on Tribunals is firmly of the view that an "upon request" reasons requirement should not be adopted. A general requirement is seen as encouraging a high standard of decision-making and consistency of decisions.

Secondly, the distinction may be important in determining the legal ramifications of a breach of the duty. What is the legal effect of a failure to give reason? Does the failure invalidate the decision itself or simply invaliditate the procedure taken subsequent to the decision? An "upon request" rule suggests that the decision and the giving of reasons are independent of each often whereas the "general obligation" suggests that a decision is not complete until reasons are given. Lastly, the "upon request" route leaves open the question of who can apply for the reasons. Must one be able to show that he is directly affected by the decision of was a party to the proceedings in order to obtain reasons?

This "upon request" route may also cause problems with the appeal process. There may be situations in which a right to reasons exists but the process for review of the decision must be initiated before reasons may

146. Compare the requirement in s. 14(1) of the Administrative Decisions (Judicial Review) Act of Australia with 5. 8(5) of the Administrative Law Act of Victoria. In one case the Attorney-General can prevent disclosure of information in the other, the Court. 
have been given. Thus a party is put in the unenviable position of seeking review without knowing the reasons for the initial decision. If reasons are only available upon request, the process of requesting reasons and the decision-makers subsequent preparation of the reasons may exhaust the period of time available to commence an appeal. The Law Reform Commission of Canada has recognized the existence of this problem. In their Report \#18, Obtaining Reasons Before Applying for Judicial Scrutiny Immigration Appeal Board, the Commission dealt with one specific instance of this problem, the Immigration Act, 1976. ${ }^{147}$ The Report outlines some of the problems which may arise - unnecessary, illformed applications for leave to appeal prepared without benefit of reasons or request for an extension of time to apply for leave. In the latter case, the "Federal Court of Appeal has said that the unavailability of reasons is not a sufficiently 'special' circumstance to warrant an extension of the time in which to apply for leave to appeal"'. ${ }^{148}$ Although the Commission stopped short of recommending that reasons be given for all decisions, the Commission recognized the value of a general reasons requirement. ${ }^{149}$ The Commission was reluctant to make such a recommendation for three reasons. First, it was too broad a recommendation in order to solve a narrow problem (their solution a two-tiered limitation period, $)^{150}$ second, the Commission is preparing to examine the right to reasons in another report ${ }^{151}$ and lastly, the danger of delay in the Board's decisions. On the last point, it should be pointed out that the Commission was not satisfied that such delays would occur, ${ }^{152}$ but simply that it might happen. As I suggested earlier, given the value of reasons, the benefit of the doubt should be exercised in favour of reasons and unless delay of a nature which is unacceptable is demonstrated to occur, reasons ought to be required.

\section{FAILURE TO COMPLY}

\section{A. MEANING OF THE TERM "REASONS"}

The last topic to be discussed concerns the effect of a decision-maker's failure to comply with a reasons requirement, whether imposed by statute or by common law. Most often, the issue will be raised in the context of alleged failure to give adequate reasons, although occasionally a

147. Supra, n. 119.

148. Law Reform Commission of Canada, Report \#18, at 5.

149. Id., at 7. " . . if reasons were given in all cases, certain economies of time probably could be realized: the need to process requests for reasons would no longer arise, and the fact that Board members would know that reasons must be produced in all cases would minimize the need for them to re-immerse themselves in the facts of the case, as they no doubt have to do now. Such a practice would also be a useful exercise in arriving at the decision itself, possibly resulting in fewer challenges of Board decisions."

150. The proposed solution would be to extend the time to apply for leave to appeal to fifteen days after receipt of reasons, where a request for reasons was made within fifteen days of the time the decision was made.

151. In the Commission's Administrative Law Working Paper \#25, Independent Administrative Agencies, the report recommended that agencies should be required to give reasons for their decision at least when requested (p. 138).

152. "Thus, although we doubt that the giving of reasons in all cases would have a significant impact on the Board's workload, ..." Supra, n. 148, at 8. 
decision-maker may simply refuse to give any reasons. ${ }^{153}$ Thus one question the court generally must answer is: What is meant by the term "reasons"?

The leading case on the meaning of the term "reasons" is a decision of Mr. Justice Megaw in Re Poyser and Mills' Arbitration. ${ }^{154}$ The case dealt with a decision of an arbitrator appointed pursuant to the Agricultural Holdings Act 1948. ${ }^{155}$ Pursuant to s. 12(1) of the Tribunals and Inquiries Act, $1958,{ }^{156}$ the arbitrator was required to state the reasons for his decision if so requested. The arbitrator gave his reasons but it was alleged by one of the parties to the arbitration that the reasons didn't respond to the substantial points which had been raised in argument before the arbitrator. An application was made to set aside the decision on the ground that the reasons given were not adequate. The applicant alleged that the failure to state adequate reasons raised an error of law on the face of the record. Mr. Justice Megaw held that the reasons were inadequate and an error of law had occurred. In his decision, he commented upon the meaning of the term reasons. ${ }^{157}$

\begin{abstract}
Parliament provided that reasons shall be given, and in my view that must be read as meaning that proper, adequate reasons must be given. The reasons that are set out must be reasons which will not only be intelligible, but which deal with the substantial points that have been raised . . I I do not say that any minor or trivial error, or failure to give reasons in relation to every particular point that has been raised at the hearing, would be sufficient ground for invoking the jurisdiction of this court. I think there must be something substantially wrong or inadequate in the reasons that are given in order to enable the jurisdiction of the court to be invoked.
\end{abstract}

In subsequent cases this view has been affirmed. In Iveagh (Earl) v. Minister of Housing, ${ }^{158}$ Lord Denning said: "The whole purpose of that enactment (section 12(1) of the Tribunal \& Inquiries Act, 1958) is to enable the parties and the courts to see what matters he [the Minister] has taken into consideration and what view he has reached on the points of fact and law which arise."159 In Givaudan \& Co. Ltd. v. Minister of Housing, ${ }^{160}$ Megaw J. re-affirmed the view he expressed in Poyser. In other cases the courts have stated that the reasons given must be sufficient to let an interested party know why a particular conclusion was reached. ${ }^{161}$ Thus the test of "proper, adequate and intelligible" reasons was established.

In Canada, the Poyser case has been adopted by the Supreme Court of Canada. In Re Northwestern Utilities Ltd. and the City of Edmonton, ${ }^{162}$ Mr. Justice Estey, speaking for a unanimous court, held that reasons

153. Re Green, Michaels and Associates Ltd. and Public Utilities Board (1978) 94 D.L.R. (3d) 641 (Alta. C.A.).

154. [1964] 2 Q.B. 467.

155. 11 and 12 Geo. 6, c. 63 .

156. $6 \& 7$ Eliz. 2, c. 66 .

157. Supra, n. 154, at 478.

158. [1963] 3 All E.R. 817.

159. Id., at 820 .

160. [1966] 3 All E.R. 696.

161. Mountview Court Prop. Ltd. v. Devlin (1970) 21 Prop and Comp Reports 689; Crake v. Supplementary Benefits Comm. [1982] 1 All E.R. 498 (Q.B. Div.).

162. Supra, n. 9. 
must be "proper, adequate and intelligible and must enable the person concerned to assess whether he has grounds of appeal".${ }^{163}$ The court held that a reason's requirement would not be satisfied by a decision maker simply saying "my reasons are that I think so". Proper reasons must reveal the reasoning process which led to the conclusions reached. In an earlier case, Dome Petroleum Ltd. v. Public Utilities Board, ${ }^{164}$ the Supreme Court affirmed a decision of Mr. Justice Sinclair of the Alberta Court of Appeal in which the Poyser case was expressly referred to and adopted.

As might be expected, the Canadian jurisprudence on the meaning of the term reasons has been greatly influenced by the decisions of the Alberta and Ontario courts, the two jurisdictions with a general reasons requirement. The Alberta Court of Appeal has in a number of cases reaffirmed the principles stated in Poyser. In the Dome Petroleum case the court stated that the reasons given by a board must enable the parties concerned to assess whether he has grounds of appeal. ${ }^{165}$ In a series of cases involving appeals from decisions of various Development Appeal Boards, the court has said that the board cannot simply parrot the statutory terms word for word as that is merely a statement of conclusion. ${ }^{166}$ The boards should give a summary of evidence, state findings of fact and explain their conclusions. However the Court of Appeal has also indicated that the whole context in which the decision was made must be considered, including the nature of the matter for decision, statutory descriptions and directions, and the arguments adduced. ${ }^{167}$ "It is apparent that each complaint of breach of s. 83(2)(b) [of the obligation to give reasons] must be adjudged on the totality of its own relevant circumstances." 168 Further, the courts have acknowledged that any standard adopted must take into account that the membership of a board may consist of persons who have no legal training. The Ontario cases adopt a similar approach. In $R e$ Canada Metal Co. Ltd. v. Macfarlane, ${ }^{169}$ a decision of the High Court of Ontario, Mr. Justice Keith indicated that the mere recitation of the statutory language is not sufficient. Nor is a summary of the proceedings. ${ }^{170}$ Reasons should contain the relevant findings and relate them to the applicable statutory standard. 171

This approach to the question of the adequacy of reasons has been echoed by the Australian courts. The Australian courts, when consider-

163. Id., at 707 (S.C.R.), 176 (D.L.R.).

164. (1977), 13 N.R. 301; The Dome case has been cited in a number of other cases, Re Hannley and City of Edmonton (1979) 91 D.L.R. (3d) 758 (Alta. C.A.), Re Green, Michaels \& Associates Ltd. v. Public Utilities Board, supra, n. 153.

165. Id., at 320.

166. Re Hannley and City of Edmonton, supra, n. 164; Re Couillard and City of Edmonton (1980) 103 D.L.R. (3d) 312; O'Hanlon v. Municip. District of Foothills H31, supra, n. 10; Murray v. Council of Municip. District of Rockyview H44 (1980) 12 Alta. L.R. (2d) 342; Noblev. County of Lethbridge \#26 Development Appeal Board (1983) 42 A.R. 222.

167. Re Couillard and City of Edmonton, supra, n. 166, p. 319-320.

168. Id., at 320 .

169. (1974), 1 O.R. (2d) 577 , at p. 587.

170. Re Dinardo and Liquor Licence Board of Ontario (1975) 5 O.R. (2d) 125 (Ont. H. Ct.).

171. Id., at 134 . 
ing the statutory requirement to give reasons found in s. 29 of the Administrative Appeals Tribunal Act $1975^{172}$ or s. 13 of the Administrative Decisions (Judicial Review) Act $1977^{173}$ have expressly referred to the Poyser case and the comments of Megaw J.174 The courts have stressed that reasons are essential for the exercise of an ef fective right of appeal ${ }^{175}$ and to overcome any grievance the person might experience when they are not told why something which affects them has been done. ${ }^{176}$

\section{B. EFFECT OF FAILURE}

A second question which arises with respect to a failure to meet a reason's requirement is the effect of the failure upon the status of the decision. Is the decision still valid and enforceable, valid but unenforceable (its applicability is held in abeyance pending the release of reasons) or invalid and unenforceable? Each view can be supported by case authority 177 and any attempt to reconcile the cases proves difficult.

One means of attempting to reconcile the cases may be to distinguish between a general reasons requirement and one which is limited to reasons upon request. Such a distinction was drawn by Le Dain J. of the Federal Court of Appeal in Alvarez v. Minister of Immigration. ${ }^{178}$ Le Dain $J$. suggested that since a mandatory reasons requirement only arose subsequent to the giving of decision, ${ }^{179}$ then the giving of reasons could not be considered a condition precedent to the exercise of the power of decision making or part of the decision proper. ${ }^{180}$ Thus any failure to give reasons could not affect the jurisdiction of the decision maker to make a decision or otherwise be an error of law in making the decision. Contrast that approach to the approach adopted by Megaw J. in Re Poyser ${ }^{181}$ in which a failure to give adequate reasons, even where the obligation only arose upon request, was found to be an error of law.

172. Supra, n. 22.

173. Supra, n. 22.

174. Re Palmer and Minister for the Capital Territory (1978-79), 23 A.L.R. 196; Collins v. Repatriation Commission (1980), 32 A.L.R. 581.

175. Collins v. Repatriation Commission (1980), 32 A.L.R. 581, at 594.

176. Burnsv. Australian National University, supra, n. 114, at 715.

177. Valid and enforceable: Proulx v. Public Service Staff Relations Board, supra, note 8; Alvarez v. Minister of Immigration (1978), 22 N.R. 85 (Fed. C.A.); Brayhead (Ascot) Ltd. v. Berkshire County Council, [1964] 2 Q.B. 303; Mountview Court Prop. Ltd. v. Devlin, supra, n. 161; Crakev. Supplementary Benefits Commission, supra, n. 161.

Valid but unenforceable: Re Temple and Liquor Licence Board of Ontario (1983), 41 O.R. (2d) 214 (Ont. H. Ct.); Beardmore v. Westinghouse Brake and Signal Co. Lid., [1976] I.C.R. 49 (Q.B. Div.).

Invalid and Unenforceable: Re Don Howson Chevrolet Oldsmobile Ltd. and Registrar of Motor Vehicle Dealers and Salesmen (1975), 6 O.R. (2d) 39 (H.C.J.D.Ct.); Givaudan \& Co. Ltd. v. Minister of Housing, supra, n. 160; Re Darnel and Pacific Pilotage Authority (1975), 51 D.L.R. (3d) 603 (Fed. C.A.); the Alberta Court of Appeal decisions, supra, n. 166.

178. Supra, n. 177. The case is also found as Re Cardona and Minister of Manpower and Immigration (1979), 89 D.L.R. (3d) 77.

179. Section 7(3) of the Immigration Appeal Board Act, R.S.C. 1970, c. I-3 provides: The Board may, and at the request of either of the parties to the appeal shall, give reasons for its disposition of the appeal.

180. Supra, n. 177 , at 87.

181. Supra, n. 154. 
The error of law approach adopted in Re Poyser has met with mixed success. Although the failure to give adequate reasons was found to be an error of law in Poyser, at least two subsequent English cases have rejected that view. In both Mountview Court Properties Ltd. v. Devlin 182 and Crake v. Supplementary Benefits Commission ${ }^{183}$ the court held that the failure to give reasons (when obliged to do so) is not in itself an error of law. In order to obtain a remedy there must exist an independent error of law, for example, improper purpose or irrelevant considerations. The Poyser decision is explained as one which "on the reasons stated, the proper inference was that there had been an error of law and that the arbitrator had misdirected himself." 184 The Canadian approach appears to be more in line with Poyser. In Proulx v. Public service Staff Relations Board, ${ }^{185}$ Le Dain J. acknowledges the debate that has occurred in England. He adopts the view that the failure to comply with the general reasons requirement would be an "error of law for which the decision could be set aside."'186 In his view, the obligation could be viewed as a mandatory procedural requirement which has not been complied with. In a more recent case, Blanchard v. Control Data Canada Ltd., ${ }^{187}$ Lamer J. of the Supreme Court of Canada expressed his view ${ }^{188}$ on the effect of failure to comply with a general reasons requirement. ${ }^{189}$ In his view failure to provide adequate reasons is an error of law on the face of the record. ${ }^{190}$ However, such an error would not affect the arbitrator's jurisdiction to hear the case and to render the decision he thinks proper unless the error is so great that it amounts to an infringement of the rules of natural justice. Such would be the case if it was impossible to understand the basis for the arbitrator's decision. Unfortunately, the issue is only given a very brief analysis and the comments are by way of obiter since Lamer J. found the arbitrator's reasons to be intelligible and sufficient to permit one to understand the basis for the decision. There is a cryptic comment which suggests that the total failure to give reasons might amount to a breach of natural justice. ${ }^{191}$ Unfortunately, Lamer J. does not expand upon this point and it is therefore unclear whether he is asserting that the failure to give any reason (where the obligation is imposed by statute) is a breach of natural justice per se.

A third method of analysis suggests that the reasons requirement and its non-performance should be analysed from the perspective of a procedural requirement which has not been complied with. This approach may stand either as a separate method of analysis or be an inherent part of the other two methods of analysis. In the two decisions of Le Dain J.

182. Supra, n. 161.

183. Supra, n. 161.

184. Mountview Court Properties Ltd.v. Devlin, supra, n. 161, p. 695.

185. Supra, n. 8.

186. Id., at 145.

187. Supra, n. 61 .

188. McIntyre J. concurred with Lamer J. The other members of the court, Bectz, Chouinard and Witson $\mathrm{J} J$., did not express any views on this issue.

189. Supra, n. 63.

190. Supra, n. 61, at 308 .

191. Id., at 308 . 
referred to earlier, he made mention of the mandatory nature of the requirement. Unfortunately, this approach is equally indeterminative. The effect of a breach of a procedural requirement upon the status of a decision is also unclear. As stated by the editor of De Smith's, "The law relating to the effect of failure to comply with procedural requirements resembles an inextricable tangle of loose ends," 192 or, as stated by the authors of Administrative Law, Cases, Text and Materials, "courts have refused to adopt a general rule of statutory construction to the effect that non-compliance with a procedural or formal requirement automatically renders a decision invalid." 193 Further, this approach leads one into quagmire of administrative law terminology - mandatory vs. directory, void vs. voidable, nullity vs. purely regulatory. It i submitted that the use of such terms is not determinative and may in fact be misleading. ${ }^{194}$ Lord Hailsham suggests that the courts must decide the legal consequence of non-compliance by considering the rights of the subject viewed in the light of a concrete set of facts and a continuing chain of events. ${ }^{195}$ At least one of the considerations appears to be whether substantial prejudice has occurred to the person complaining of the breach. ${ }^{196}$ Further the importance of the provision that has been disregarded and the relation of that provision to the general object intended to be secured by the legislation should be considered. ${ }^{197}$ Or as stated by one commentator: "Often in determining the rigour with which a statutory requirement to give reasons must be obeyed, the courts will take into account the policy underlying such a procedure." 198 For example, in Proulx, Chief Justice Jackett, speaking for the majority, said that the primary function of reasons is not to ensure that justice is done but is to attempt to make the parties (particularly the unsuccessful party) realize that the matter has been dealt with in an unbiased judicial manner and thus, by making the decision more acceptable make it more probable that the process will serve its objective of substituting due process for anarchy. ${ }^{199} \mathrm{He}$ further held that reasons also serves to ensure that the tribunal has satisfied itself that it has dealt with all relevant problem in a proper legal manner. ${ }^{200} \mathrm{Mr}$. Justice Le Dain, in his dissent, stressed the importance of reasons as a means of providing a basis for review, a matter of secondary importance to the majority. In another case, Re Don Howson Chevrolet ${ }^{201}$ reasons were required to be given whenever the Registrar of Motor Vehicles Dealers and Salesman proposed to suspend or revoke the registration of a salesman or dealer. Without reasons, the essentials of the case that the

192. Supra, n. 5, at 142 .

193. Authored by J.M. Evans, H.N. Janisch, D.J. Mullan and R.C.B. Risk (2nd ed. 1984) 288.

194. London and Clydeside Estates Ltd. v. Aberdeen District Council, [1980] I W.L.R. 182 (House of Lords), p. 189. See also Mullan, Developments in Administrative Law: The 1982-83 Term (1984), 6 Supreme Court L.R. 1 at 32-37.

195. Id., at 189.

196. DeSmith's Judicial Review of Administrative Action, supra, n. 5, at 143.

197. Howard v. Bodington (1876-77) 2 P.D. 203.

198. R.A. Macdonald, M. Paskell-Mede, "Annual Survey of Canadian Law: Administrative Law" (1981) 13 Ottawa Law Review 671, at 728.

199. Supra, n. 8, p. 141.

200. Id. n. 8 at 141, n. 6 .

201. Supra, n. 177. 
dealer or salesman had to meet were lacking. The Ontario Divisional court held that giving of reasons was a condition precedent to the process of revocation or suspension. (Even Mr. Justice Jackett in Proulx suggested that the deprivation of a person's status in the economic world might require all formal procedural requirement be met.) ${ }^{202}$ Further, the inability to raise certain grounds of appeal, such as irrelevant consideration, may occur if reasons were not given when required. ${ }^{203}$

The result of this analysis reveals that the courts have not adopted a consistent approach to the effect of the failure to give reasons. Although the courts all accept the proposition that a duty to give reasons (if imposed by law) should be enforceable, presumably through the remedy of mandamus or its counterpart, ${ }^{204}$ the courts have not determined conclusively the consequences of the failure. The cases and decisions suggest that the courts are troubled by the concept of striking down a decision which otherwise appears valid merely because of a failure to meet the reasons requirement. In part this may reflect the differing views expressed upon the underlying value of reasons, in part simply that no "substantive" error has been demonstrated. As a means of resolving this conflict, I suggest a compromise - a middle route which affirms the importance of reasons but also preserves the accepted principles of judicial review.

First, any decision which is subject to a reasons requirement (whether imposed by statute or by common law) and which fails to meet this requirement (either by the total absence of reasons or by the failure to provide adequate reasons) should be considered to be a valid but incomplete decision. As such, the decision is not enforceable until complete.

Second, a duty to give reasons should be enforceable by the writ of mandamus or a similarly equivalent remedy.

Third, upon the issuance of adequate reasons (or a court's determination that the reasons given are adequate) the decision shall be considered to be complete and enforceable. However, the decision would still be subject to any legal challenge, including judicial review or appeal (where applicable) to determine its validity independent of the failure to give reasons.

This approach attempts to meet the problems created by the failure to give reasons and yet, at the same time, not unduly disrupt or interfere with the administrative process. Further, it is consistent with the principles of judicial review. If a duty exists, that duty should be enforceable; if an error has occurred which supports judicial interference, then the decision should be invalid. Yet the failure to give reasons does not necessarily mean an error of law (independent of the failure to give reasons) has occurred. Nor does the failure to give reasons invariable mean that a person has been denied an adequate opportunity to present

202. Supra, n. 8 at 141, n. 4.

203. O'Hanlon v. Municipal District of Foothills $\# 31$, supra, n. 10.

204. "There seems to be general agreement in the authorities that such a requirement (obligation to give reasons) is mandatory in the sense that a mandamus should lie to compel compliance with it, but there have been an apparent difference of view as to whether a failure to comply with the requirement is an error of law." Mr. J. Le Dain (in dissent) in Proulx v. Public Service Staff Relations Board, supra, n. 8, at 145. 
their side of the case. However, without reasons, it is difficult, if not impossible, to determine whether an error of law has occurred or whether natural justice has been denied. Proper reasons would indicate if such defects have occurred. Why require the decision maker to re-hear and reconsider the whole matter if all that has been omitted is an explanation of the reasons. A more appropriate remedy is simply to order an explanation of the decision, the giving of reasons. The decision maker is compelled to rationalize the decision with the evidence and arguments presented. Once reasons have been given, the parties may decide their next step. Once reasons have been given, the court, upon an application for review, is able to determine if any illegality has occurred. Thus the proposal renders the decision ineffective as being incomplete until reasons have been given.

\section{CONCLUSION}

The right to reasons, although universally acclaimed by academics, government and the courts, appears to be an idea whose time has not yet come. Although the concepts of natural justice or fairness would appear to support the imposition by the courts of a right to reasons, the courts have been reluctant to do so. The enactment of $s .7$ of the Charter would appear to provide one more opportunity for a judicially created right to reasons. However, given court's past reluctance to impose a reasons requirement it is unlikely that the mere enactment of $s .7$ will be sufficient to change the court's opinion.

Why the judicial reluctance to impose a reasons requirement? Possibly the courts are reluctant to legislate by judicial fiat. The legislatures, both federal and provincial, have the power to impose a reasons obligation upon their statutory creations. Some provinces, Ontario and Alberta in particular, have imposed a general right to reasons. Other jurisdictions have acted on a board by board basis. The courts may see the failure of the legislature to act as a signal that a right to reasons is not needed nor desired. Alternatively, the courts may be concerned about the effects of a right to reasons rule. Upon which decision makers should the obligation be imposed? Should there be exceptions? What are adequate reasons? What is the effect of failure to comply? Again the courts may be reluctant to answer these questions without at least some guidance from the legislatures.

Yet similar justifications and concerns could be expressed about the two current branches of natural justice; the right to be heard and the right to an unbiased decision maker. The courts have acknowledged their power to impose a right to be heard even where the statute in question is silent. ${ }^{205}$ Nor have the courts refused to impose a right to be heard simply because the existence of a right requires an elaboration of the content and scope of the right. Thus, although the judicial reluctance to impose a right to reasons may be explained, it should not be condoned. Reasons form an integral part of natural justice because reasons ensure that the other two branches have been complied with. If the judiciary accept the

205. Cooperv. The Board of works for the Wandsworth District (1863) 143 E.R. 414; Nicholson v. Haldimond-Norfolk Regional Board of Commissioners of Police, supra n. 70. 
role of guardians of natural justice, then the imposition of a reasons obligation is not only consistent with that role, it assists the court in maintaining their role.

Once the right has been established, whether by the courts or by the legislature (or by both) questions arise as to its operation. Upon whom, to whom, in what situations? As indicated, the scope of the rule should be as broad as possible, possibly broader even than the concept of fairness. A presumption in favour of reasons should exist. Those who assert that the obligation is too onerous, impracticable or dangerous should carry the burden of persuasion. Further, decisions which fail to meet the reasons obligation should be considered to be incomplete. These decisions would be held in abeyance pending the issuance of reasons.

Lord Mansfield is reported to have said, upon advising a general who, as governor of a West India Island, had also to sit as a judge:206

Be of good cheer - take my advice, and you will be reckoned a great judge as well as a great commander-in-chief. Nothing is more easy; only hear both sides patiently - then consider what you think justice requires, and decide accordingly. But never give your reasons - for your judgment will probably be right, but your reasons will certainly be wrong.

Until the obligation to give reasons is imposed upon decision makers, the attitude expressed by Lord Mansfield will continue, to the detriment of us all.

206. J. Campbell, Lives of the Chief Justices, vol. 2. p. 572 quoted in P. Jackson, Natural Justice (1979), p. 97. 